\title{
"WeAKLYNGes" sucking at England: ReAssessing the Scottish Plantation of UlsteR ${ }^{1}$
}

\author{
John Sherry*
}

In a letter to the earl of Northampton in February 1608, Sir Arthur Chichester, $1^{\text {st }}$ Viscount Belfast and Lord Deputy of Ireland, referred to Ireland and Scotland as "weaklynges," believing both to be a drain on English resources. Chichester, a leading architect of the Plantation of Ulster along with the Attorney-General of Ireland, Sir John Davies, believed that by allowing the Scots to participate in an English project of civilising Ireland, they would in turn become less burdensome to England. He, however, saw Scottish involvement as a practicality, not the beginning of an ideological movement designed to create closer ties between the two Stuart kingdoms already linked through the 1603 Union of the Crowns. Such moves by King James VI and I had already proved fruitless, failing to convince his English and Scottish subjects of the benefits of a political union. ${ }^{3}$ Despite migration between Scotland and Ulster occurring prior to the seventeenth century, this had largely been of a Catholic nature between Highland and Irish clans, personified by the settlement of Clan Donald in the Glynns of Antrim from the fifteenth century onwards. ${ }^{4}$ This migration had proved so formidable that the English Tudor administration reluctantly agreed in 1586 to grant land on the north Antrim coast to the clan

\footnotetext{
* John Sherry is a post-doctoral fellow in the history of Scotland and Ulster at the University of Guelph, having been awarded a PhD from the University of Ulster in 2009 for his examination of Scottish commercial and political networks in Ulster, 1688-1714. His current research interest is the links between early modern Ireland and Scotland within a wider British and Atlantic context.
} 
leader, Sorley Boy MacDonnell, in order to prevent an alliance with rebellious clans at war with the English in Ireland. Unlike the Highland links to Ireland, very little migration took place between Protestant Lowland Scotland and Ulster prior to 1600. Protestant Scots sought adventure and employment in other parts of Europe.

At the turn of the seventeenth century, Scotland was very much a culture of mobility, with the recent works of Steve Murdoch and David Worthington, amongst others, showing that Scots could be found throughout continental Europe. ${ }^{5}$ Yet, a part of this diaspora largely overlooked, most probably due to its close proximity to Southwest Scotland, is Ireland, in particular the province of Ulster. Throughout the seventeenth century migration to Ireland occurred, and reached its peak during the $1690 \mathrm{~s}$ when 40-70,000 Scots arrived. ${ }^{6}$ This last migration stream should be seen in the proper context of Scotland having an approximate population of one million people at that time. Thus, approximately five percent of the Scottish national population migrated to Ireland in this decade alone. The purpose of this paper is twofold; first, to re-examine the traditional historiography of the Plantation of Ulster and argue that there is a need for this to be re-addressed to encompass the entire seventeenth and early eighteenth century in order to fully appreciate its scale and success. Second, to highlight Scottish involvement in the project to show how important a role sustained Scottish migration played in the Plantation of Ulster.

It had been the intention of English monarchs to rule Ireland since the mid-twelfth century, when in 1169 King Henry II received authorisation from Pope Alexander III to annex Ireland and "perform there the things that have regard to the honour of God and the salvation of that land."7 Not until the sixteenth century, however, 
could England claim to have any tangible control over Ireland; even then this authority only covered the Pale of Dublin and strategic eastern and southern towns such as Cork, Drogheda, Limerick and Waterford. Through military conquest and planting of English subjects, the Tudor queens, Mary and Elizabeth, attempted to settle the midland counties of Leix and Offaly, renamed King's and Queen's Counties respectively, and the southern province of Munster. Although described by Steven Ellis as a "struggling English colony" and an "expensive failure," English government support does show a Tudor policy of commitment to subjecting Catholic Ireland to English rule. While the Munster Plantation failed to attract the 8,400 migrants the government had desired only 4,000 New English ${ }^{9}$ settlers arrived - it nevertheless demonstrated an English determination to plant loyal subjects to combat the "uncivilised" Gaelic Irish prior to the 1603 Union of the Crowns with Scotland when King James VI of Scotland succeeded Queen Elizabeth as James I of England.

As ruler of both kingdoms, James had to contend with three problematic regions of his kingdoms: the Anglo-Scottish Border, the Scottish Highlands and Islands, and Ireland - in particular the most rebellious province of Ulster. Of the three regions geographically, the Borders proved the easiest to contend with. Yet, due to differences in English and Scots law, it proved problematic to reach a consensus. Prior to 1603, English and Scottish governments had worked together to pacify the area, and, in 1605, a body of ten conjunct commissioners, five each from Scotland and England, had been appointed to ensure the region be "reduced to obedience." 10 In a speech to the English Houses of Parliament in 1607, King James claimed that the Borders "are as fruitfull and as peaceable as most parts of England." 11 This was most certainly an exaggeration on the part of the king, who had ulterior motives in trying to unite his two kingdoms politically, but by the end of James' reign 
a degree of law and order had been established in the Borders. ${ }^{12}$ Yet, other parts of Scotland proved to be more problematic.

Scottish government policy towards the Highlands from 1580-1617 changed regularly; from 1596 onwards, Michael Lynch describes it as repeated attempts to "conquer Highland society or beat it into civilisation." 13 After a successful conquest of the Hebridean Isles in 1608 led by Andrew Stewart, third Lord Ochiltree, this policy altered to one of civilising the region, and used clans loyal to the Crown, most notably the Campbells, to enforce law and order. ${ }^{14}$ Despite the continued existence of some troublesome clans, the government viewed the region as having been pacified during James' reign. ${ }^{15}$ Nevertheless, as trouble continued to flare throughout the seventeenth and eighteenth centuries, culminating with the third Jacobite rising of 1745-6, such government views of the region proved somewhat optimistic and premature, if not foolish.

Tied to the Highland problem was that of Ulster. In order to secure the Highlands, the links to Gaelic Ireland, where Ulster acted as a crossroads, had to be severed. During the reign of Queen Elizabeth I of England (1558-1603), the Highlands had acted as a recruiting ground for Irish chieftains, with many mercenaries, known as the Gallowglass, deployed in Ulster. Thus, from a "British" perspective the Plantation of Ulster of the seventeenth century was an attempt to pacify the most rebellious Irish province by settling loyal subjects, largely Protestant, from both England and Scotland and to supplement the New English in Ireland in creating a Protestant government able to effectively govern a Catholic majority. From a Scottish perspective, the intended aim had also been to have a community to act as a barrier between Ireland and the Highlands.

For Scottish involvement of a Protestant nature in Ireland, the first meaningful migration to Ulster sanctioned by the government began in 1605. Importantly, 
this settlement took place prior to the conceiving of any official plantation scheme in the region. In this year, King James confiscated the Clandeboye estates, known as the Great Ards, from Conn O'Neill in the north of County Down, and divided them between two members of the Southwest Scottish gentry, James Hamilton ${ }^{16}$ and Hugh Montgomery. ${ }^{17}$ They each received a third of O'Neill's lands and conspired to capture the remainder over the following years. In using families predominantly from Southwest Scotland to plant their lands, the region increasingly developed a distinct Scottish identity. Both men and their families became major landowners in Northeast Ulster and members of the Irish nobility in 1622, Hamilton ennobled as Viscount Clandeboye and Montgomery as Viscount Montgomery.

Following the Flight of the Earls ${ }^{18}$ in 1607, and Sir Cahir O'Doherty's rebellion ${ }^{19}$ in 1608, the English government declared nearly 3,800,000 acres of land in Ulster forfeit, and this would come to be the basis for the Ulster Plantation. King James envisioned great plans for his Scottish subjects in Ulster, seeing the Plantation as a way to help integrate his Scottish and English kingdoms and fashion his vision of a "Greater Britain." The awarding of 81,000 acres to fifty-nine Scottish undertakers - only 500 acres less than the fifty-one English undertakers received - in Counties Armagh, Cavan, Donegal, Fermanagh and Tyrone, shows that purely from a numerical viewpoint, the Scots would be treated as equals. ${ }^{20}$ Only in the newly created county of Londonderry did James not allocate lands to the Scots; these lands had been specifically put aside for the London Companies to plant. ${ }^{21}$

While the Plantation of Ulster has been covered in great detail by academics, the greatest emphasis has been placed on the initial years of this venture. With the exception of the London Companies' interest in the 
planting of County Londonderry, Sir Nicholas Pynnar's survey, first commissioned in 1618 and completed in 1619 , and a 1622 report was the last formal government involvement in the project. 22 These reports found that approximately 6-7,000 Scottish adults had settled in the six Plantation counties, 3,740 (57\%) of whom were men. ${ }^{23}$ Over $70 \%$ of the Scottish undertakers succeeded in settling their estates with the required numbers: twentyfour men for each 1,000 acres, including ten different families. Yet, the same number of Scottish estates failed to build any defensive works of note, compared with their English counterparts' more impressive rate of $87 \%$. However, in breaking down these statistics Southwest Scottish undertakers proved the most successful in the running of their estates, compared to those from other parts of Lowland Scotland and England. Whilst those from Lowland Scotland successfully planted 44\% of their lands, those from the Southwest had a success rate of $68 \% .{ }^{24}$ This figure is comparably more substantial when it is considered that of the nine unsuccessful undertakers from this region, over half received lands in the baronies of Boylagh and Banagh, situated in what turned out to be barren and uninhabitable land on the northwest coast of Donegal.

Official and unofficial Scottish migration to the counties of Antrim and Down, those closest to Scotland, actually generated greater numbers than that of the combined British migration to the six official plantation counties of Ulster. By 1622, due to the private Hamilton and Montgomery settlements in this region since 1605 , approximately 4-5,000 men could be raised in defence, the overwhelming majority of Southwest Scottish origin. ${ }^{25}$ By the death of King James in 1625, approximately 15,000 Scots had settled throughout Ulster, with a similar number of English settlers also, giving a total settlement of approximately 30,000. ${ }^{26}$

The death of King James marks a key date in the historiography of the Ulster Plantation. In his major 
work, The Scottish Migration to Ulster in the Reign of James I, first published in 1973, Michael Perceval-Maxwell evaluates migration up to 1625 . This might at first appear to be a logical time to argue the end-point for the Plantation as it had widely been viewed as King James' personal project, even if he had become disillusioned in the latter years of his reign due to the slow nature of settlement. In his 1993 article, "The Origins of the Scottish Plantation in Ulster to 1625," J. M. Hill also evaluated Scottish involvement up to 1625 , using the death of James, like Perceval-Maxwell, as a logical end to his work. Yet, whilst the planners of this project, the king included, had held optimistic, but somewhat unrealistic, goals for a quick solution to the Ulster problem, it had become abundantly clear from an early stage that a successful plantation would involve more than a single wave of migration, certainly more substantial in numbers than had been achieved by 1625 . Therefore, to confine the Ulster Plantation to the reign of James would be shortsighted, and must be viewed as a longer process than the life of the king. Thus, the works of Hill and PercevalMaxwell, while providing in-depth analysis of Scottish involvement in the origins of the Plantation, should be viewed only as valuable case studies of King James' attempt to implement the initial stage of subjugating Catholic Ireland to the rule of Protestant England.

A key period when analysing the Ulster Plantation and its success is the first genuine attempt by the native Irish to rebel against the conditions imposed on them. This first occurred in any meaningful context in 1641, when on 23 October a native rebellion attempted to overthrow the English government in Dublin, and a mass uprising took place in Ulster to reclaim the land lost to the English and Scottish planters. This, coupled with the Covenanting rise to power in Scotland and the tensions between King Charles I and the English Parliament, effectively brought the three Stuart kingdoms into an open conflict that would last into the $1650 \mathrm{~s} .{ }^{27}$ As 
such, the 1641 Irish Rebellion, or the end of the War for the Three Kingdoms in the early 1650s, is viewed by many as the end of the Ulster Plantation, as most of the settlers who had not been killed in 1641, had fled to England, Scotland, Wales and the Isle of Man as refugees. ${ }^{28}$ Yet, at the time of the outbreak of the Irish Rebellion, approximately 40-45,000 British migrants had settled in Ulster, and those of Scots descent accounted for over half this number. ${ }^{29}$

Some of the most respected plantation scholarship uses 1641 and the Irish Rebellion as the end of the official plantation. Amongst those who have used this event as an end point are T. W. Moody and Raymond Gillespie. Moody's The Londonderry Plantation - 1609-41, published in 1939 , is a leading text that conveys this point, and analyses the emergence of County Londonderry from the beginning of the Plantation to the Irish Rebellion. ${ }^{30}$ Gillespie's 1985 publication, Colonial Ulster - The Settlement of East Ulster, 1600-1641, examines Counties Antrim and Down, two of the three Ulster counties that were not part of the official plantation - Monaghan being the third. ${ }^{31}$ His work has proven crucial to understanding Scottish settlement in these two counties which surpassed the total official British settlement in the six planted counties. ${ }^{32}$ A key consideration for 1641 is the belief that the resulting warfare ended migration to Ireland. Yet, even Gillespie dispels this myth asserting that the Irish Rebellion proved to be a major catalyst in restructuring Irish society, and that later seventeenth century East Ulster was radically different to pre-1641 in terms of population and dynamics of growth. ${ }^{33}$ The Plantation had not come to an end - it had stalled amidst a failure of the English government and the king to actively support the project. On seeing this opportunity, the native Irish grasped their chance to reclaim control of their country.

The collapse of British rule in Ireland in 1641 and 1642 , and the subsequent warfare, raises questions over the success of the Plantation, for its ultimate goal had 
been to prevent a Gaelic Irish uprising similar to those of pre-1603 and 1608. Not until the Cromwellian Conquest, beginning in 1649 and continuing throughout the 1650s, when the English New Model Army crushed the native Irish threat, could Ireland be considered subdued. One of the more recent works concerning the Ulster Plantation, but within a much wider analysis of the conquest of Ireland, is Nicholas Canny's Making Ireland British 1580-1650. Canny concludes that only after the New Model Army had defeated the Irish Confederation in the late $1640 \mathrm{~s}$ and early $1650 \mathrm{~s}$ that a conquest of Ireland ever nearly came to fruition. ${ }^{34}$ Although the Catholic Irish owned less than a quarter of all profitable land by 1660, Canny concludes that the conquest of Ireland, including that of the Ulster Plantation, proved to be unsuccessful, and a costly failure as English and Scottish settlers did not control enough land and political power in Ireland. ${ }^{35}$

As migration to Ulster recommenced in the $1650 \mathrm{~s}$, it is difficult to place Ulster within a larger conquest of Ireland. While other settlement attempts may have come to a halt at this point - the exception being English Cromwellian settlers of the 1650s, ${ }^{36}$ Ulster continued to recover from the warfare of the $1640 \mathrm{~s}$. Indeed, very few plantation scholars have linked the migration streams of post-1660 to those of pre-1641. Phillip Robinson is one who does make this connection, arguing that the Ulster Plantation continued until 1670, as only then did the last of the six different phases of influx and colonisation of Ulster come to an end. ${ }^{37}$ Yet, his analysis, and that of much of the Plantation historiography, is problematic in that it negates the largest single migration of the seventeenth century to the region, that of the Scots to Ulster in the 1690s, which surpassed the total number of English and Scottish migrants up to 1641.

While the Plantation was essentially an English project, by trying to fit it into an English model, some of the more important Scottish aspects of the venture have 
been neglected. More recent scholarship on Protestant Ireland from the 1640 s onwards, in particular that of Toby Barnard, offers a different perspective on the impact of the Plantation. His major works, $A$ New Anatomy of Ireland - The Irish Protestants, 1649-1770 and Irish Protestant Ascents and Descents, 1641-1770, focus on the evolution and consolidation of Protestant Ireland. ${ }^{38}$ Describing English progress towards its goals in Ireland by 1641 as "erratic and disappointing," 39 Barnard suggests little progress had been made up to this point, only with the outbreak of warfare in Ireland in 1641, followed by the confiscation of Catholic lands in the 1650s, did the original English goal of a fully functioning Protestant Ascendancy begin to be fully implemented by the descendants of the settlers. 40

If Barnard's argument that the Protestant Ascendancy developed from the 1650s onwards, then it is necessary to understand who resettled and rebuilt Ulster in the aftermath of the fighting of the 1640s. From the Restoration period onwards, migration to Ulster became an almost exclusive Scottish experience, with a further 10,000 Scots migrating during the reigns of King Charles II (1660-85) and King James VII and II (168588). ${ }^{41}$ These incoming migrants originated overwhelmingly from Southwest Scotland, a Presbyterian heartland which at that time faced systematic persecution from the Scottish government for non-conformity. Further evidence that the majority of new migrants to Ulster in the second half of the seventeenth century were Scots comes from Jean Agnew's study of the Belfast merchant community, in which she explains that from the 1650s onwards virtually all newcomers to Belfast were of Scottish origin and that contemporaries perceived the town by the late 1670 s to be Scottish. ${ }^{22}$ This new wave of Scottish migrants, whilst welcomed by the Ascendancy in the respect that it bolstered Protestant numbers in Ireland - Protestants regardless of denominational affinity constituted less than $15 \%$ of the total population 
in Ireland - did create an understandable fear that Presbyterianism in Ulster would soon command greater numbers than the Church of Ireland.

To gain a fuller understanding of the longevity and durability of the Plantation, it is vital to see events in seventeenth-century Ireland as a continuation of events, rather than a series of separate episodes. Of the academics that have written on the issue, Robinson offers the longest timeframe to 1670 . By halting at 1670 Robinson fails to discuss the impact one of the most important events in early modern Irish and British history, the Glorious Revolution of 1688-91, had on the Ulster Plantation. According to eminent Irish historian, Louis Cullen, the importance of the seventeenth century to Ireland was that it acted as "the transition from medieval to modern." ${ }_{33}$ The Revolution played a vital role in this transition. Academics of British and European history are sometimes too quick to talk of a "Long Eighteenth Century" beginning in 1688, suggesting that the Revolution acted more as a defining event for what would unfold in later years. ${ }^{44}$ However, by doing so there is a failure to realise that the Revolution was a continuation of events of the seventeenth century, and only its outcome in Ireland, namely the dominance of the Anglo-Irish Protestant elite, should be classed as part of the "Long Eighteenth Century." 45 Therefore, it is to the outcome of the Williamite War in Ireland that academics must look to as evidence of achieving the ultimate Plantation goal of suppressing Gaeldom and establishing a Protestant administration that could effectively govern Ireland. ${ }^{46}$

Although it is widely believed that Scottish migration to Ulster peaked during the reign of King James VI, this is not the case. Indeed, as recent analysis by Patrick Fitzgerald has shown, Scottish migration to Ulster reached its pinnacle during the 1690 s when approximately 40-70,000 settled in the province; many came because of the pull factor of the cheap rents after the devastation of the Williamite War, whilst many others 
were pushed towards Ulster in the later 1690s because of severe famine in Scotland from 1695-99. In total, this 1690s migration was up to three times the volume of Scottish migration up to $1641 .{ }^{47}$ Furthermore, this migration was larger than the joint British venture to Ulster prior to 1641 . Indeed, the scale of migration proved so extensive by 1691 that the Scottish Privy Council took action against any tenants fleeing and prevented boats from transporting people without official passes. ${ }^{48}$

Although the number of Scots migrating to Ulster during the 1690s was undoubtedly on a large scale, it should not be forgotten that the last quarter of the early eighteenth century saw the beginning of emigration from Ulster to North America. Thus, a key reason for expanding the scope of the Plantation to include Scottish migration to Ulster in the 1690 s and early $1700 \mathrm{~s}$ is because it is a key link in the process of onward migration to North America. Despite recognising the importance of this later migration, no specific work deals with the Scots in Ulster post-1690.49 Thus, recent scholarship is only beginning to touch upon the importance of later Scottish migration to Ulster, but not to the level that is necessary.

The introduction of Presbyterianism to Ulster in the seventeenth century is arguably the greatest significance of Scottish involvement in the Plantation. When Scots Protestants first began to arrive, they adhered to the Episcopal Church, and therefore would have subscribed to the Anglican Church of Ireland. This occurred in the initial years of the Plantation, but from the 1620 s onwards Presbyterianism began to develop in Ulster. Yet, this was slow to develop, with seventeenth-century reports by the Presbyterian ministers, Patrick Adair and Andrew Stewart, castigating the lack of values in the planters. Born in Galloway, Southwest Scotland, Adair, the first historian of the Presbyterian Church in Ireland, 
rebuked early Scottish planters for their lackadaisical attitude towards religion. 50 Stewart, the son of a planter and Presbyterian minister at Donaghadee, County Down, from 1645 to 1671 , went further in his criticism, famously noting; "from Scotland came many ... and from England not a few; yet all of them generally the scum of both nations." 51 As most Scots in Ulster prior to the 1640s remained Episcopalian, they readily identified with the emerging Church of Ireland. At this time, however, the Established Church had little impact throughout Ireland, except in areas that had a strong English or Scots presence. The Anglican failure to impose itself in Ulster meant that no clear doctrine could be promoted, and created an environment in which a small number of radical Scottish ministers, most notably Robert Blair and John Livingstone, could promote Calvinist ideas not acceptable to the Churches of England or Scotland. The preaching of these ministers in the 1620 s and early 1630 s can be seen as the origins of a distinct Scottish community in Ulster that would go on to become the Presbyterian Church. Indeed, Patrick Adair described Blair as "that famous minister of Christ ... who was the first and greatest instrument for preaching of the Gospel in the north of Ireland," 52 such was the high regard Presbyterians in Ulster had for him.

Under the newly appointed Lord Deputy of Ireland, Thomas Wentworth, the Church of Ireland took on an increasingly coherent ideology more in line with that in England. This new dawn in the Church of Ireland's history jeopardised the small enclave of Presbyterian Scottish settlers in Ulster whose beliefs were now deemed radical. Thus, ministers like Blair and Livingstone found themselves deposed from their positions as part of Wentworth's overall strategy to reform the Church of Ireland. ${ }^{53} \mathrm{~A}$ failed attempt to migrate to colonial America led them to return to Scotland where they became part of a wider radical group in the southwest of the country. ${ }^{54}$ In Ireland, however, Wentworth's 
suppression of religious radicalism continued, where he rigorously implemented an oath of association, known as the Black Oath, on all Scots in Ulster. Given the choice between fining and imprisonment or to swear their loyalty to King Charles I over the Covenanters, the Scottish Presbyterians who had rejected attempts by Charles to impose religious conformity on the Church of Scotland, generally conformed. ${ }^{55}$

While the 1641 Irish Rebellion proved a major challenge to the Ulster Plantation, it inadvertently led to the formal establishment of the Presbyterian religion in Ulster. In the summer of 1642 a Scottish Covenanting army, consisting of over 10,000 men, landed in Ulster to defend the English and Scots in the region. As Scotland had abolished Episcopacy in 1638 and created a Presbyterian church and government, it looked to export the Presbyterian religion throughout the three Stuart kingdoms. Thus, on 10 June 1642, five army chaplains who had accompanied the army formed the first official presbytery in Ireland, consisting entirely of soldiers. ${ }^{56}$ From then onwards Presbyterianism had an official foundation in Ulster from which it could grow. This move by the Covenanting regime also showed their intention to plant a Presbyterian "party" in Ulster to guard against any future threat to Scottish security, both domestically and in Ireland. This objective can further be seen in the Solemn League and Covenant, a religious-military alliance between the parliaments of England and Scotland signed in September 1643 that saw the Covenanters intervene in the English Civil War against King Charles I. Article one of the alliance called for the "preservation of the reformed religion in the Church of Scotland" and the "reformation of religion in the kingdoms of England and Ireland." 57 Whilst the treaty encouraged the spread of Presbyterianism in these two regions, ultimately relations between the English and Scottish Parliaments deteriorated and led to the Cromwellian Conquests of Scotland and Ireland, and the 
removal of the Presbyterian Covenanting leadership in the $1650 \mathrm{~s}$.

By the time of the Restoration of King Charles II in 1660 , the number of presbyteries in Ulster had increased to five, ${ }^{58}$ which provided a central leadership and discipline that proved vital for the consolidation and growth of a Scottish Presbyterian community. Although still a minority in Ulster, when the Presbyterians began to establish an economic and religious independence from the Anglican Ascendancy in Dublin, fears arose in the government that the Presbyterians would be less likely to accept their authority as the rightful rulers of the evolving Protestant Irish society. ${ }^{59}$ This autonomy from state control, however, led the more religiously inclined members of the Ascendancy, most notably the clergy of the Church of Ireland, to view the Presbyterians as a distinct threat to the Established Church.

These tensions deepened in 1672 when King Charles II granted the Regium Donum, an annual stipend intended to pay the Presbyterian ministers in Ireland. To the Anglicans in Ireland this equated to royal recognition of a growing sect. Consequently, relations continued to deteriorate between the two groups, and even during times of war against a Catholic enemy in 1689-91, these sectarian tensions flared between the two Protestant groups, most notably during the 105 day Siege of Derry, from 18 April until 28 July 1689. Despite facing a much greater threat in the shape of mobilised Catholic Irish army determined to place the deposed Catholic monarch, James VII and II, back on the thrones of England and Scotland, trouble between Anglicans and Presbyterians continued in the town. Many pamphlets published in the aftermath of the siege demonstrate these tensions, and even disputed each others roles in the defence. ${ }^{60}$ When Governor George Walker and other leading non-Presbyterian defenders received special praise at the expense of others, ${ }^{61}$ it led to multiple replies by other inhabitants, most notably John Mackenzie, who 
took great exception to Walker's failure to properly note the role of the Presbyterians. MacKenzie mocked Walker's leadership and favouring of Anglicans, stating; "For as to the Enemy, he was a Man of peace all this time, and was guilty of Shedding no other Blood to Stain his Coat with, but that of the grape." 62

Presbyterian historian, Finlay Holmes, describes the year, 1690, as marking the "end of the beginning of Irish Presbyterian history,"63 referring to the first meeting of the Synod of Ulster. This proved to be the beginning of an institution that would rival the Church of Ireland, and act as a regional seat of government for Presbyterians in Ulster, and other Presbyterian congregations in Ireland that accepted the Synod as the head of the Presbyterian Church. By the end of 1690 the Synod of Ulster oversaw nine presbyteries, three sub-synods and 120 congregations, and, Patrick Griffin estimates, over 150,000 Presbyterians. ${ }^{64}$ From this point onwards the Presbyterian Church had a larger membership than the Church of Ireland in Ulster. As a result, Anglicans looked to contain the threat by excluding Presbyterians from the power in postRevolution Ireland. They did this by continually petitioning the Lords Justices of Ireland concerning the expansion of the Presbyterian Church beyond Ulster, by claiming that Presbyterian factions dominated all trade in the province and by creating a general fear that Presbyterians intended to oust all Anglicans from power in Ireland. ${ }^{65}$ Whilst these claims had been based on circumstantial evidence or loose interpretations of the truth, it does show the fears of the Church of Ireland that Scottish Presbyterians now dominated Ulster not only in numbers, but also in local politics.

Although the defeat of the Jacobites by 1691 did not end the threat of a Catholic resurgence in Ireland, Anglicans still chose to punish non-conforming Protestants, particularly Ulster Presbyterians. Even as early as the summer of 1695, prior to the convening of the Irish Parliament that initiated the Penal Laws, the Irish 
Chancellor, Sir Charles Porter, motioned that there soon could be a time when Anglicans would have to re-arm Irish Catholics to counter the supposed Presbyterian threat in Ulster. 66 Porter's views echoed those of leading Church of Ireland bishops, who believed that the renewed Scottish Presbyterian settlement in Ulster during the 1690 s posed a great threat to the government and the Established Church. ${ }^{67}$

The greatest attack on Scottish Presbyterians came in the shape of the passing of the 1704 Act to prevent the Further Growth of Popery, an act initially directed towards Catholics, but eventually encompassed all who refused to conform to the Church of Ireland. ${ }^{68}$ This legislation applied to all persons who held public office, either in parliament or at a local level. The intended targets had been Presbyterian merchants who controlled the affairs of some of the leading towns in Ulster. In Londonderry, nine aldermen and twenty-four burgesses (64\% of the total town corporation) resigned their positions from the town corporation, whilst six of the twelve members of the Belfast Corporation were removed from Belfast in 1707 after a parliamentary investigation. ${ }^{69}$ This legislation had intentionally targeted Scottish Presbyterians because of their success as merchants in Ulster, and effectively curbed their power in local politics.

Despite the size of the Scottish Presbyterian community in Ulster and their involvement in local politics, it would be wrong to think that they dominated the affairs of the province. This can be seen in the Williamite land confiscations of the 1690s and early 1700s, where those who supported the claim of James VII and II had their land declared forfeit. A total of 567,877 acres of land was made available, but only 19,797 acres in Ulster. ${ }^{70}$ The only notable Scot in Ulster who invested in the confiscations was James Anderson, a Belfast merchant of Glasgow origins. Anderson bought a total of 1,583 acres in the Ulster counties of Antrim, Down, as well as lands in 
Kildare and Kilkenny.71 Thus, Ulster Presbyterians with the exception of the town of Londonderry, where Presbyterian merchants dominated local affairs, did not have any real control in the province, other than of the size of their religious community. Whilst the impact of the new wave of Scottish migration should not be understated, their actual impact on the planning and administration of the Ulster Plantation at this time should not be overstated.

One area in which Scottish involvement in the Plantation proved crucial, however, was in developing the province as an economic centre. Prior to 1600, Ulster had been economically underdeveloped in comparison to the provinces of Leinster and Munster. By the end of the century Ulster could no longer be classed as the poor province of the Irish economy. Beyond Dublin the region could be considered a most vibrant part of the national economy, with towns such as Belfast, Carrickfergus, Coleraine, Londonderry and Newry to a lesser extent, flourishing. It had not been envisaged that Belfast and Londonderry would become the leading ports in the region; it had been expected that Carrickfergus and Coleraine would become the focal points of trade. Coleraine had been identified as a key port where English planters would settle, and Carrickfergus already had a small English community prior to $1600 .{ }^{72}$ By 1700, Belfast and Londonderry, both noted for their substantial Scottish populations, easily outperformed the other ports, demonstrating that over the long term Scottish involvement in the Plantation was imperative for its growth and success. Indeed, Scottish involvement in substantial trade had already been noted in a 1637 report by the Surveyor-General, Charles Monke; "the Scots, being many in number, and twenty to one for the English, having privy trade in the town and country, thrive and grow rich." 73

By the 1630s Belfast had replaced Carrickfergus as the largest port in Ulster, but only Ireland's joint ninth 
largest port with Londonderry, both accounting for three per cent each of the total Irish customs. ${ }^{74}$ In the $1690 \mathrm{~s}$, however, Scottish dominance of Ulster trade led to one contemporary claiming in 1696 that "the Scots have gott into their Hands two-thirds of the Trade of Ireland ... Belfast is now counted the Second place of Trade in Ireland, yet the Scotch Merchants are Spread into all the other Trading Townes of that Kingdome."75 To claim that the Scots controlled so much national trade is a gross exaggeration, but is a fair assessment of their role in Ulster, with Belfast growing to rival any Irish port with the exception of the capital, Dublin.

In order to gain a fuller perspective of the Plantation of Ulster it is necessary to view the event as a century-long process. Leading academic works have focussed on the Plantation on the short or medium term without fully realising that the Revolution of 1688-91, and the ensuing mass migration of Presbyterian Scots to Ulster, played integral roles in the project. Scottish planters outnumbered their English counterparts at the beginning and end of the seventeenth century, and Counties Antrim and Down had overwhelming Scottish populations, despite not having been part of the official Plantation scheme. Even to this day these counties have a strong sense of connection to the Ulster-Scots of the seventeenth century. By planting these two counties, the Scots not only offered a blueprint for the future planting of Ulster, but also helped to make the Plantation a province-wide project. But Scottish involvement proved to be more than just numbers. As the seventeenth century progressed, the Presbyterian Church in Ulster evolved from a small group of preachers in the 1620 s to the largest Protestant Church in Ulster by the turn of the eighteenth century. Furthermore, their numbers helped to reinforce the Protestant population in Ulster after the wars of the 1640 s and 1688-91, whilst their role in the 
defence of the province during the Revolution has been well documented. Large-scale migration of Scots to Ulster in the final decade of the seventeenth century doubled the amount of Protestants in Ulster and helped to soothe the threat of future Jacobite risings. The legacy that Scottish involvement had on the Ulster Plantation was not only in the number of settlers, but in developing the Presbyterian religion in Ireland. Numerically, the Scots played a substantial role in settling Ulster and when Sir Arthur Chichester referred to the Scots as "weaklynges" in the early seventeenth century and promoted their involvement in the Ulster Plantation, he could not have known how vital they would be to its development and longevity. Within a century, the Scots in Ulster were no longer weaklings but the largest settler group in the province. 


\section{Notes}

1 This paper was first published as "'Weaklynges' sucking at England: A reassessment of Scottish involvement in the Plantation of Ulster" in M. Hay, ed., Institute of Ulster-Scots Studies, Working Papers, Vol. I(Ulster: University of Ulster, 2009), 45-57. All copyright was retained by the author.

2 Sir Arthur Chichester to the Earl of Northampton, 7 February 1608. J.P. Prendergast, (ed), Calendar of State Papers, Ireland, James I, 1606-1608 (London: Her Majesties Stationery Office, 1874), 404-5. M. Perceval-Maxwell, The Scottish Migration to Ulster in the Reign of James I (London: Routledge and Kegan, 1973), 77.

${ }^{3}$ K.M. Brown, Kingdom or Province? Scotland and the Regal Union, 1603-1715 (New York: St Martin's Press, 1992), 86-94.

${ }^{4}$ J.H. Ohlmeyer, Civil War and Restoration in the Three Kingdoms The Career of Randal MacDonnell, marquis of Antrim, 1609-1683 (Cambridge: Cambridge University Press, 1993), 18. D. Stevenson, Scottish Covenanters and Irish Confederates (Belfast: Ulster Historical Foundation, 1981), 4. For a more detailed account see G. Hill, ed., Historical Account of the MacDonnells of Antrim (Belfast: Archer, 1873), and H. MacDonald, The Wild Geese of the Antrim MacDonnells (Dublin: Irish Academic Press, 1996).

5 A. Grosjean and S. Murdoch, eds., Scottish Communities Abroad in the Early Modern Period (Leiden: Brill, 2005). S. Murdoch, Network North - Scottish Kin, Commercial and Covert Associations in Northern Europe, 1603-1746 (Leiden: Brill, 2006). D. Worthington, Scots in the Habsburg Service, 1618-1648 (Leiden: Brill, 2004). D. Worthington, ed., British and Irish Emigrants and Exiles in Europe, 1603-1688 (Leiden: Brill, 2010).

${ }^{6}$ J.R. Young, "Scotland and Ulster in the seventeenth century: the movement of people over the North Channel," in Ulster and Scotland, 1600-2000 - History, Language and Identity ed. W. Kelly and J.R. Young (Dublin: Four Courts Press, 2004), 12.

7 "The Bull Laudibiliter," in English Historical Documents, vol II 1042-1189, ed. D. Douglas and G.W. Greenaway (London: Eyre and Spottiswoode, 1961), 776-7. J. Byrne, "The Trembling Sod: Ireland in 1169," in A New History of Ireland, Volume II - Medieval Ireland. 1169-1534, ed. A. Cosgrove (Oxford: Oxford University Press, 1987), 41.

8 S.G. Ellis, Ireland in the Age of the Tudors, 1447-1603 - English Expansion and the End of Gaelic Rule (London: Longman, 1998), 279. 
9 The term "New English" refers to English Protestants who migrated to Ireland from the mid-sixteenth century onwards. Prior to the rule of Henry VIII and the English Reformation, all English migrants in Ireland were members of the Catholic Church. They were known as the "Old English," and so the term "New English" was used to differentiate the English Protestant settlers from the English Catholic settlers.

${ }^{10}$ D. Mason, ed., The Register of the Privy Council Records of Scotland, 1604-1607 (Edinburgh: Her Majesties General Registrar, 1885), 702.

11 "A Speech to both the Hovses of Parliament, Delivered in the Great Chamber at White-Hall, the last day of March 1607," King James VI and I - Political Writings, ed. J.P. Somerville (Cambridge: Cambridge University Press, 1994), 169. The Earl of Dunfermline had also informed King James in 1609 that the Borders were "als lawfull, als peciable and als quyett as anye pairt in any ciuill kingdome of Christianite." Letters and State Papers during the Reign of King James the Sixth, (Edinburgh: Abbotsford Club, 1885), 171-3.

12 A. Groundwater, "The chasm between James VI and I's vision of the orderly 'Middle Shires' and the 'wickit' Scottish Borderers between 1587 and 1625," Renaissance and Reformation, xxx (4) (2006/07), 126.

13 M. Lynch, "James VI and the 'Highland problem," in The Reign of James VI, ed. J. Goodare and M. Lynch (East Linton: Tuckwell Press, 2000), 211.

14 A.I. Macinnes, Clanship, Commerce and the House of Stuart, 16031788, (East Linton: Tuckwell Press, 1996), 60. Clan Campbell also referred to itself as "North British" to emphasize its commitment to King James' attempts to further the Union of the Crowns. See Bond by Archibald, earl of Argyll, to Sir Duncan Campbell of Glenurquhay for 800 merks when granter receives from the king a heritable title of office of general justiciary of North Britain, 2 July 1607 (National Archives of Scotland, GD112/1/378).

15 Lynch, "James VI and the 'Highland problem,"' 226.

16 R.J. Hunter biography of James Hamilton in the Oxford Dictionary of National Biography, http://www.oxforddnb.com/view/article/12086?docPos=10. The eldest son of Hans Hamilton, James Hamilton graduated from the University of St Andrews. In 1587, Hamilton had been appointed a schoolmaster in Dublin. He also acted as an agent for King James VI. With the establishment of Trinity College Dublin, Hamilton was appointed as a fellow in 1592 and a bursar in 1598. A strong supporter of Scottish military involvement in Ulster prior to 1603 , 
Hamilton was a keen supporter of the Plantation of Ulster, despite not receiving any land himself.

${ }^{17}$ For more on Hugh Montgomery, see G. Hill, The Montgomery Manuscripts (Belfast: Archer, 1869).

18 The Flight of the Earls is the term used to describe the actions of Hugh O'Neill, first Earl of Tyrone, and Rory O'Donnell, first Earl of Tyrconnell, along with approximately ninety close friends and family, who fled Ulster for continental Europe in September 1607. The Earls, the leading Gaelic figures in Ulster at the time, had fled as a result of English government policy that had encroached on their lands. Furthermore, O'Neill feared that a summons to London to answer charges against him relating to a domestic quarrel would lead to his imprisonment.

${ }^{19}$ Sir Cahir O'Doherty's rebellion in 1608 lasted eleven weeks before he was shot and killed at Kilmacrenan, County Donegal, on 5 July 1608. The scale of the rebellion can be seen from Sir Arthur Chichester's appeal to the Scottish government to send troops to help suppress it. Two hundred Scottish troops were sent to Ulster, although the rebellion was over by the time they arrived.

O'Doherty's lands in the Inishowen peninsula of Co. Donegal were given to Chichester as part of the official plantation scheme.

${ }^{20}$ For a break down on the fifty-nine Scottish undertakers, see Appendix 6 in P. S. Robinson, Plantation of Ulster-British Settlement in an Irish Landscape, 1600-1670 (Dublin: St Martin's Press, 1984), 205-8. For the English undertakers, see Appendix 5, 202-5.

${ }^{21}$ Prior to the Plantation the lands that became County Londonderry were parts of Counties Coleraine and Donegal. Coleraine was abolished and Londonderry became the new county. This county came under the control of the Honourable the Irish Society, an organisation formed in 1613 to oversee the London Livery Companies interest in the Ulster Plantation.

${ }^{22}$ G. Hill, ed., An Historical Account of the Plantation in Ulster at the Commencement of the Seventeenth Century, 1608-1620 (Belfast: McCaw, Stevenson and Orr, 1877), 449.

${ }^{23}$ A copy of the Pynnar survey can be found in Hill, An Historical Account of the Plantation in Ulster, 445-590. Perceval-Maxwell, The Scottish Migration to Ulster, 207, 228.

${ }^{24}$ J. M. Hill, "The Origins of the Scottish Plantation in Ulster to 1625: A Reinterpretation," in Journal of British Studies, xxxii (1993), 33-4.

${ }^{25}$ Perceval-Maxwell, The Scottish migration to Ulster, 250-1. 
${ }^{26}$ R. Foster, Modern Ireland, 1600-1972 (London: Allen Lane, 1988), 72-3.

27 The warfare of the 1640s in the three Stuart Kingdoms has been referred to as the English or British Civil War. However, "the War for the Three Kingdoms" is a phrase used more commonly in the recent writing of Irish and Scottish history.

${ }^{28}$ For the impact of refugees in Scotland see Young, "Scotland and Ulster;" For the impact in England see K.J. Lindley, "The impact of the 1641 rebellion upon England and Wales 1641-5," in $I H S$, xviii (1973), 143-76; E. H. Shagan , "Constructing Discord: Ideology, Propaganda, and English Responses to the Irish Rebellion of 1641," in Journal of British Studies, xxxvi (1997), 4-34.

${ }^{29} \mathrm{M}$. Bennett, The Civil Wars in Britain and Ireland 1638-1651 (Oxford: Blackwell, 1997), 14-5.

30 T. W. Moody, The Londonderry Plantation, 1609-41 - The City of London and the Plantation in Ulster (Belfast: William Mullan and Son, 1939).

${ }^{31}$ R. Gillespie, Colonial Ulster - The Settlement of East Ulster, 16001641 (Cork: Cork University Press, 1985).

32 Ulster muster roll, c. 1630 (BL, Add mss 4770); Perceval-Maxwell, Scottish Migration to Ulster, 250-1.

33 Gillespie, Colonial Ulster, 223-4.

${ }^{34}$ N. Canny, Making Ireland British 1580-1650 (Oxford: Oxford University Press, 2003), 577-8.

35 Ibid, 578.

${ }^{36}$ See K. S. Bottigheimer, English Money and Irish Land - The 'Adventurers' in the Cromwellian Settlement of Ireland (Oxford, Clarendon Press: 1971).

${ }^{37}$ Robinson, Plantation of Ulster, 97, 106-7.

38 T. Barnard, A New Anatomy of Ireland - The Irish Protestants, 16491770 (Yale: Yale University Press, 2003); T. Barnard, Irish Protestant Ascents and Descents, 1641-1770 (Dublin: Four Courts Press, 2004). A smaller, yet equally useful, publication is T. Barnard, The Kingdom of Ireland, 1641-1760 (Basingstoke: Palgrave Macmillan, 2004).

39 Barnard, The Kingdom of Ireland, p. 2.

${ }^{40}$ For a fuller explanation of the Irish Protestant Ascendancy, see S. J. Connolly, Religion, law, and power: the making of Protestant Ireland, 1660-1760 (Oxford: Oxford University Press, 1992) and D. Dickson, New Foundations: Ireland, 1660-1800 (Dublin: Irish 
Academic Press, 2000).

${ }^{41}$ Young, "Scotland and Ulster," 12.

${ }^{42} \mathrm{~J}$. Agnew, Belfast Merchant Families in the Seventeenth Century (Dublin: Four Courts Press, 1996), 13.

${ }^{43}$ L. M. Cullen, The Emergence of Modern Ireland 1600-1900 (London: Holmes and Meier, 1981), 25.

${ }^{44}$ For example, P. Langford, ed., Short History of the British Isles The Eighteenth Century, 1688-1815 (Oxford: Oxford University Press, 2009), and F. O'Gorman, The Long Eighteenth Century - British Political E Social History, 1688-1832 (London: Hodder Arnold, 2007).

45 For example, A New History of Ireland, Volume IV: Eighteenth Century Ireland 1691-1800, ed. by T. W. Moody and W. E. Vaughan (Oxford: Oxford University Press, 2009), R. Gillespie, Seventeenth Century Ireland (Dublin: Gill and Macmillan, 2006) and P. Lenihan, Consolidating Conquest - Ireland 1603-1727 (Harlow: Pearson Longman, 2008).

${ }^{46}$ From 1695 onwards, the Irish government in Dublin passed the Penal Laws, legislation designed to further reduce Irish Catholicism to obedience and consolidate the Anglo-Irish position. Most of these laws remained on the statute book until the later eighteenth century, although some lasted beyond the 1800 Act of Union between Ireland and Great Britain, most notably the issue of Catholic emancipation, only finally removed in 1829.

${ }^{47}$ P. Fitzgerald, "Scottish Migration to Ireland in the Seventeenth Century," 29. P. Fitzgerald, “Black 97': reconsidering Scottish migration to Ireland in the seventeenth century and the Scotch-Irish in America," 72.

${ }^{48}$ Register of the Privy Council of Scotland, 1691, xvi, (Edinburgh: General Register Office for Scotland, 1971), 651-2.

${ }^{49}$ See the following for more information on Ulster Emigration to North America in the Eighteenth Century: R.J. Dickson, Ulster Emigration to Colonial America, 1718-1775 (London: Routledge and Kegan Paul: 1966). P. Griffin, The People with No Name - Ireland' Ulster Scots, America's Scots Irish, and the Creation of a British Atlantic World, 1689-1764 (Princeton: Princeton University Press, 2001).

50 P. Adair, A True Narrative of the Rise and Progress of the Presbyterian Church in Ireland (1623-1670), (Belfast: Aitchison, 1866), 9.

${ }^{51}$ Cited in Hill, Historical Account, 447.

52 Adair, True Narrative, 9. 
${ }_{53}$ M. Perceval-Maxwell, "Strafford, the Ulster-Scots and the Covenanters," Irish Historical Studies, xviii (1973), 525-6.

${ }^{54}$ A. I. Macinnes, The British Revolution, 1629-1660 (Basingstoke: Macmillan, 2005), 113. Young, "Scotland and Ulster in the seventeenth century," 13-4. Blair, who became a minister in Ayr, and Livingstone, a minister at Stranraer, both became part of the Covenanting movement in Scotland that rejected King Charles I's attempts to impose the English Book of Common Prayer on the Church of Scotland in the summer of 1637.

55 R. P. Mahaffy, ed., Calendar of State Papers relating to Ireland, of the reign of Charles I, 1533-1647 (London: Her Majesties Stationery Office, 1901), 222-3. Examples of punishments are recorded in this source, a prime one being logged on 7 September 1639 when Henry Stewart and others were fined and imprisoned for life for refusing to take the Black Oath.

${ }^{56}$ Adair, True Narrative, 92-5.

${ }^{57}$ S.R. Gardiner, ed., The Constitutional Documents of the Puritan Revolution, 1625, 1660 (Oxford: Clarendon Press, 1906), 268.

58 These were located in Antrim, Down, the Route (located in upper County Antrim), Laggan and Tyrone.

${ }^{59}$ Connolly, Religion, law, and power, 170-1.

${ }^{60}$ Many pamphlets were published in the immediate aftermath of the Siege of Derry that show the high level of animosities between the Anglicans and Presbyterians in the town, including Anon, Observations upon Mr Walkers account of the Siege of London-derry with some remarks on the great and memorable actions there done (London: R. Simpson, 1689); J. MacKenzie, Dr. Walker's Invisible Champion Foyl'd, or, An Appendix to the Late Narrative of the Siege of Derry wherein all the Arguments offered in a late Pamphlet to Prove it False Libel, are Examin'd and Refuted (London: Booksellers of London, 1690); J. MacKenzie, Narrative of the Siege of London-Derry, (London: Booksellers of London, 1690); G. Walker, $A$ Vindication of the True Account of the Siege of Derry in Ireland by Mr. George Walker (London: Rob. Clavel, 1689).

61 The Journals of the House of Commons, 1688-1693, x (127 vols. London: House of Commons, 1803), 290.

62 MacKenzie, Dr. Walker's Invisible Champion Foyl'd, 8.

${ }^{63}$ F. Holmes, The Presbyterian Church in Ireland - A Popular History (Dublin: The Columba Press, 2000), 49.

${ }^{64}$ Griffin, The People with No Name, 19; Holmes, Presbyterian Church in Ireland, 49; Connolly, Religion, Law, and Power, 167. 
${ }^{65}$ Petition from the Bishop of Down to the Lords Justices in Ireland, Spt. 1698 (National Library of Scotland, Wodrow, MSS, Quarto XXVIII, no. 44. F. Brewster, A Discourse Concerning Ireland and the Different Interests Thereof, in Answer to the Exon and Barnstaple Petitions Shewing, That if a Law were Enacted to Prevent the Exportation of Woollen Manufactures from Ireland to Foreign Parts, What the Consequences Thereof Would be Both in England and Ireland (London: E. Whitlock, 1698), 34. W. Tisdall, The Conduct of the Dissenters of the Kingdom of Ireland, With Respect both to Church and State (Dublin: Unknown publisher, 1712), 25.

66 Sir Charles Porter to Sir William Trumbell, 9 July 1695 (HMC Downshire (75), I, 500-1).

67 The Bishop of Derry, William King, estimated 30,000 Presbyterians had arrived in his diocese alone from 1690 to 1994. W. King, An admonition to the dissenting inhabitants of the diocese of Derry concerning a book lately published by Mr J. Boyse, entituled, Remarks on a late discourse of William, Lord Bishop of Derry

(Dublin: Andrew Crook, 1694), 4, 7.

68 G. Grierson, ed., The Journals of the House of Commons of the Kingdom of Ireland, From the Fifth day of October, 1692, Inclusive, in the Reign of King William and Queen Mary, to the Twenty-fourth day of December, 1713, Inclusive, being the End of Queen Anne's Parliaments (third edition, Dublin, 1796), 373-7, 451-2. An Act to Prevent the Further Growth of Popery was made law in 1704, which prevented all non-conformists in Ireland from serving in Parliament, the military, or on Town Corporations. This act, also referred to as the Sacramental Test Act, was originally part of the Penal Laws against Catholics. However, a clause that stipulated any person who did not receive communion at a Church of Ireland service was inserted, and so deemed Presbyterians as non-conformists unfit for public office. This act had little impact in Parliament itself, Presbyterian MPs constituting less than three per cent. The intended aim of this bill was to end Presbyterian power of the town corporations in Ulster, where they were highly influential.

${ }^{69}$ Corporation of Londonderry Minute Book, 2, (Harbour Museum, Londonderry), 256; R.M. Young, ed., The Town Book of the Corporation of Belfast, 1613-1816 (Belfast: Robert Magill, 1892), 198.

70 Antrim $=7,134$ acres, Armagh $=1,170$ acres, Cavan $=1,508$ acres, Londonderry $=80$ acres, Monaghan $=224$ acres, Tyrone 9,681 acres.

${ }^{71}$ A summary of the Trustee's sales can be found in Simms, J.G., The Williamite Confiscation in Ireland, 1690-1703 (Westport:

Greenwood Press, 1976), 348-96. Anderson bought 732 acres in 
Antrim, 558 in Down, 257 in Kildare, and 36 in Kilkenny.

72 Hill, An Historical Account of the Plantation in Ulster, 374-5.

${ }^{73}$ Customs, Excise, \& c. in Ireland, A. D. 1637. Extracts from report on the State of the Customs by Charles Monke, Surveyor-General, to Sir George Ratcliffe, 1637. R.M. Young, ed., Historical Notices of Old Belfast and its Vicinity (Belfast: Marcus Ward, 1896), 42-8.

${ }^{74}$ Cited in R. Gillespie, Early Belfast - The origins and growth of an Ulster town to 1750 (Belfast: Ulster Historical Foundation, 2007), 89.

75 Papers relating to Ireland trade, 1695-97 (British Library, Sloane MS 2902, f. 218); A.I. Macinnes, Union and Empire: the Making of the United Kingdom in 1707 (Cambridge: Cambridge University Press, 2007), 190; S. Murdoch, Network North - Scottish Kin, Commercial and Covert Associations in Northern Europe 1603-1746 (Leiden: Brill, 2006), 242-3. 